\title{
Establishing Maximum Size Expectations for Urban Trees with Regard to Designed Space
}

\author{
Jessica Sanders, Jason Grabosky, and Paul Cowie
}

\begin{abstract}
One issue confronting the application of forest management principles to urban tree canopy management decisions is the lack of data correlating site, tree size, and tree age. Researchers tested whether terminal size (stem diameter) can be linked to site type for informed management and design decisions. Data were considered from eleven New Jersey, U.S. communities. Diameter breast height (DBH) distribution established regionalized service life expectancies of commonly planted species by site type and expected maximum DBH. The goal was to develop a method to identify trees approaching senescence within an inventory. Three common urban landscape site types were used: tree pit, planting strip, and unlimited soil. Thirty-one taxa were present in large enough populations to use in species-specific analysis. The species were classified into small, medium, and large size categories based on published growth expectations. The study authors developed DBH occurrence percentiles, and DBH within the ninety-fifth were described as a maximum size range. There was a significant difference in maximum sizes between planting site types. Regardless of the size class of the tree, the data showed reduced planting space resulted in reduced maximum size.

Key Words. Age Class; Canopy Management; New Jersey; Senescence; Site Type; Urban Forest; Urban Tree Growth.
\end{abstract}

Urban trees are both a public asset and a public risk. As a result, management planning is required to address and balance both appropriate public values and expenses. A tree inventory is necessary to best manage public trees. An inventory typically includes the total number of trees, species composition, tree location, and tree condition to provide a better context for informed management decisions. Unfortunately, inventories often lack interpretive ability or an established method for effective management of age structure and sustainability within a mixedspecies (and thus mixed maximum size) urban tree population.

The process of plant selection to match urban tree species to varied, and often difficult, urban planting sites is a fundamental aspect of urban environmental design and management. However, establishing expectations for performance over time is often only implied as establishment success is the short-term goal and performance evaluation criteria are lacking. Urban areas are quite heterogeneous, and environmental stresses may vary considerably, even among adjacent planting sites. Berrang et al. (1985), studying more than 80 variables for 375 trees planted near the Consolidated Edison facilities in New York City, New York, U.S., found that excess soil moisture, mounding of soil on roots, soil salts, and overall root system size were the most important factors affecting a tree's overall health. Chacalo et al. (1994) surveyed 1,261 street trees in Mexico City, Mexico, collecting data for seven different variables, concluding that problems with overall tree health could be attributed to planting in inappropriate locations, overall species choice, and lack of adequate planning and maintenance. Both of these studies concluded that planting selection becomes a site-specific challenge, and by extension, growth capability follows suit.
General wisdom might suggest that urban design forms should provide a metric for visual evaluation to assist management decisions. While there is a general understanding of soil biotic capacity and carrying capacity in the management of natural forested systems, the urban context of biotic capacity and carrying capacity is far behind the natural forested areas. Additionally, observations of tree performance in response to soil opening size (Grabosky and Gilman 2004; Day and Amateis 2011; Sanders and Grabosky 2013) suggest merit for an approach to understanding biotic capacity within an urban design context. Indeed, as major projects (e.g., PlaNYC, Million Trees Philadelphia, Miami, Los Angeles) are increasingly evaluated within a context of sustainability, the ability to predict plant performance and longevity with relation to design choices is crucial for an appropriate program analysis. Planting spaces in urban design are usually reflective of three different sites: tree pit, planting strip, and non-limited soil. 'Non-limited' included all trees where the area underneath the dripline of a tree was unpaved. An example would be the soil available to a tree planted in a park or in a lawn setting. 'Planting strip' had less available soil per tree, best described as the strip of ground where the available soil is bordered on two sides by structures or pavement thus limiting the tree root zone. 'Tree pit' included a cutout, tree-well, or raised planter, where available soil was extremely limited, meaning the available soil was less than the drip line of the tree.

Without a method of defining a useful end point to urban tree service life, there remains difficulty in developing a public acceptance or management plan for tree harvest and replacement in urban tree populations. The logistics of tree service life, removal, and replacement include the planning and timing of 
maintenance activities, removal of trees, selection of new suitable species, and location of planting stock for replacement, all while managing public relations, politics, and risk liability or management. Managing urban forests most often occurs over a time frame that exceeds any one manager's tenure. Jim (1994) states that the many facets of managing tree replacement can be a daunting challenge to urban tree managers and Hitchmough (1994) concedes that complexity and political nuances of the task are typical excuses for inactivity. Managing urban tree replacement is not a new problem (Solotaroff 1911). Pescott (1968), when addressing the planned replacement of trees, indicates that as early as 1954, in England, a government committee of relevant experts was formed to advise the Ministry of Works on the felling and planting of trees in all types of locations. Four decades later, Hitchmough (1994) claimed, "many landscape management organizations are not adequately prepared to cope with problems of this intensity and magnitude." By developing a repeatable method to define and explain removal and replacement, a management conversation, and the requisite outreach program to inform the public, can be implemented.

Sinclair and Hudler (1988) define the "decline" of trees, as opposed to natural senescence, as "a premature progressive loss of health, distinguished from the normal occurrence of senescence by premature debilitation." However, there is no current definition of premature death due to the fact that there are no established definitions for normal rates of attrition and life expectancies for trees in the urban settings. Although anecdotal field wisdom exists, lifespan has not been defined in the research record for most urban tree species within an urban context. Sinclair and Hudler (1988) further developed four major aspects of tree decline: three describing disease, pests, and environmental stresses; and the fourth describing synchronous cohort senescence (trees of similar age growing in groups have a tendency to display group behavior, such as shared patterns of senescence). Researchers of the current study sought to develop a better understanding within this fourth area of decline, acknowledging that the planting site types suggested earlier define an evaluation or management expectation, but are associated with imposed environmental stresses.

Trees in the urban context are planted in many different site typologies that cover a multitude of variables. Although complete site analysis could be performed on every tree, this is neither efficient nor does it provide a general model for assessing trees. Using available soil surface as a visual site type characteristic may allow managers to better assess the conditions of the current urban forest and provide better information for future plantings and design evaluation. Interpretation of tree size within a site can vary depending on the location. As a hypothetical example, a $51 \mathrm{~cm}$ DBH Quercus rubra is common and considered very large in a sidewalk zone in the study location, but it is very rare to see a $61 \mathrm{~cm} \mathrm{DBH}$ tree in this zone. The same tree would be considered a mid-range size for the species if found as a park or yard tree within visual distance of the sidewalk zone. Cornus florida or Tilia tomentosa would have differing profiles. Choices of plant placement in design require an understanding of maturity and longevity expectations.

Apparent available soil is certainly not the only variable that affects or informs the expectation of a tree's overall health, longevity, and maximum size. However, it is an easily managed, recordable, and cataloged characteristic that can help predict what other variables may have an effect. The associa- tion provides a prediction of tree growth behavior, reflective of the earlier observations of Grabosky and Gilman (2004), not a causation of the phenomena. In application, site type could later be combined with work suggested by Bond $(2010 ; 2012)$ in examining the condition of the tree, especially in its characteristic profile in context with its expected maximum size.

Urban trees are often planted with an expectation of nearly zero attrition, in spite of ample experience to the contrary, thus skewing major portions of the urban canopy towards one age class and minimizing urban forest sustainability (Clark et al. 1997). As a consequence, researchers have little knowledge of what might be considered a reasonable life span for any number of common species, design situations, urban gradients, soil disturbances, or environmental ranges. Urban forestry has historically emphasized tree planting and survival, with little attention directed to what constitutes mature and overmature trees in the urban forest, or how common design responses affect ultimate tree size or service. Managing the urban forest within the traditional knowledge of forests, researchers are unable to address stand longevity or a harvest interval.

This study focuses on the harvest interval by deriving a methodology to define overmature trees, and provide a context for developing an urban size expectations to help define harvest interval. The specific goals of this study were to develop a better understanding of senescence in urban tree populations and how different planting design choices might influence mature size expectations. As a motivation for management, the repeatable method can begin to define and explain removal and replacement by establishing a definition for overmature trees and determine expected harvest intervals for species.

\section{MATERIALS AND METHODS}

The current study included community inventories collected throughout northern and central New Jersey, U.S., by a consultancy firm that was hired to develop the inventories as part of a state-wide program for the development of community forest management plans (NJ DEP Division of Parks and Forestry 2011). Eleven communities were inventoried between 1995 and 2010; the resulting database is composed of approximately 45,500 trees and more than 280 taxa. Data collected included tree diameter at breast height (DBH), planting site type, planting site area, tree species, tree genus, and maintenance recommendations. ANOVA was used to determine if communities could be grouped. Percentiles on trunk DBH were then developed based on the multi-community data.

Three specific sites were defined that were based on available soil: non-limited, planting strip, and pit. To avoid bias created by a single town's maintenance and care, only the taxa that were found on all three site types across at least three inventories were analyzed and included in this study. In addition to groupings by available soil, trees were also grouped according to maximum height in a park-like setting (Table 1). Small species were considered to be any tree in which maximum height at maturity was less than $9.1 \mathrm{~m}$, medium tree species were greater than $9.1 \mathrm{~m}$ but less than $15 \mathrm{~m}$, and large tree species were greater than 15 m (Gerhold et al. 1993; Hightshoe 1988; Bassuk et al. 2009).

Since this study focused on maximum size, the trees in each species were ranked into DBH percentiles as an aggregated species grouping across all communities within each site type. For each 
species-site cohort, those within the ninety-fifth percentile were described as the maximum size range (Table 2). This is a standard procedure for ranking populations in epidemiology and educational tests, and works well for the purposes of the study (Cannell 1988; Fraenkel and Wallen 1992; Schoonjans et al. 2011). The logic is that trees no longer occurring above a certain size class were removed because of excessive size for the planting site; removed due to declining vigor or condition; or died before exceeding the observed terminal limit size. The smallest number of trees considered acceptable for inclusion within a particular site type had to be greater than seven, which was required for at least one tree for inclusion into the 95th percentile rating. For 95th DBH percentile species-specific analyses, 27,986 trees were examined.

Of the 280 taxa analyzed, 31 taxa were present in large enough populations to tabulate within the size classification. Of those 31 , eleven qualified for a formal species-specific analysis on whether there is a difference in site type for maximum observed stem diameter size In this context, the term overmature is used to draw attention to the lack of trees in a larger category, which infers loss of the species from the inventory on some level. Data were analyzed for those 11 species occurring on all three types of sites using the null hypothesis of: no difference in terminal size within species across the three soil types. A one-way ANOVA was used to determine if there was a statistical significance between the within-species size classes in each site type.

Then DBH values within each species were then normalized against their associated species maximum for inclusion in the general linear model. This allowed for between species comparisons despite differences in their species-specific size distributions and expectations, allowing multiple species to be grouped together into small, medium, and large tree types. As a relative scale, the species were stacked together for a general linear model on size (small, medium, large) and site (pit, strip, non-limited), with an interaction term. There were a total of 41,771 trees examined for analysis in the general linear model. This analysis proved general trends across species based on maximum plant size versus site type. A Bonferroni analysis was done on the interaction data means for DBH. All analysis was conducted in MiniTab 14.1, after the data met all assumptions for statistical analysis and alpha was set at 0.05 .

\section{RESULTS}

The 11 species used in the species-specific analysis represented 27,986 trees, or $61.6 \%$ of the general database population (Table 1). It was found that in all 11 species that met the requirements for inclusion into the data analysis, site type made a significant difference in maximum observed size. Trees that had more available soil grew larger than trees that had small amounts of soil.

All 31 species included in Table 1 were large enough populations to potentially define a species overmature rating for north-central New Jersey communities. The 31 species used in the general linear model accounted for 41,771 trees or $92 \%$ of the total inventory population. Maximum DBH in small, medium, and large trees varied based on planting typologies. The general linear model showed that there was a statistically significant difference $(p<0.001, S D=18.1)$ between maximum DBH in small, medium, and large trees in the tree planting typologies (non-limited, planting strip, and tree pit) (Table 3). There was also a statistically significant interaction
Table 1. Trees observed in complete urban municipal tree census inventories from 11 communities across north-central New Jersey. A listing of the most common species occurring in each size class by planting zone typology, their occurrence in the data set, and the maximum range observed DBH. Entries in bold italic were used within species-specific analysis, given their occurrence in adequate numbers across all planting typologies.

\begin{tabular}{|c|c|c|c|}
\hline \multirow[t]{2}{*}{ Species } & \multicolumn{3}{|c|}{ Planting zone typology } \\
\hline & Pit & Strip & Non-limited \\
\hline \multicolumn{4}{|l|}{ Small } \\
\hline Acer palmatum & 0 & 7 & 84 \\
\hline Cornus florida & 0 & 16 & 304 \\
\hline Prunus serrulata & 1 & 87 & 770 \\
\hline Syringa reticulata & 8 & 107 & 34 \\
\hline \multicolumn{4}{|l|}{ Medium } \\
\hline Acer campestre & 0 & 45 & 61 \\
\hline Carpinus betulus & 1 & 263 & 44 \\
\hline Cladrastis kentukea & 0 & 18 & 62 \\
\hline Phellodendron amurense & 1 & 14 & 60 \\
\hline Picea pungens & 0 & 6 & 178 \\
\hline Prunus yedoensis & 0 & 3 & 165 \\
\hline Pyrus calleryana $^{\mathrm{z}}$ & 136 & 714 & 687 \\
\hline Sophora japonica & 4 & 24 & 76 \\
\hline \multicolumn{4}{|l|}{ Large } \\
\hline Acer platanoides & 94 & 4052 & 3304 \\
\hline Acer pseudoplatanus & 0 & 14 & 69 \\
\hline Acer rubrum & 30 & 1404 & 2408 \\
\hline Acer saccharinum & 8 & 530 & 392 \\
\hline Acer saccharum & 30 & 694 & 1280 \\
\hline Aesculus hippocastanum & 9 & 49 & 89 \\
\hline Gleditsia triacanthos & 60 & 225 & 507 \\
\hline Platanus $\times$ acerifolia & 43 & 1411 & 883 \\
\hline Prunus serotina & 0 & 13 & 618 \\
\hline Quercus alba & 3 & 9 & 226 \\
\hline Quercus bicolor & 5 & 69 & 140 \\
\hline Quercus coccinea & 3 & 39 & 262 \\
\hline Quercus palustris & 66 & 1973 & 3358 \\
\hline Quercus phellos & 8 & 36 & 172 \\
\hline Quercus rubra & 32 & 337 & 1494 \\
\hline Quercus velutina & 1 & 20 & 205 \\
\hline Tilia cordata & 32 & 332 & 551 \\
\hline Ulmus americana & 11 & 60 & 339 \\
\hline Zelkova serrata & 47 & 529 & 343 \\
\hline
\end{tabular}

${ }^{\mathrm{z}}$ Cultivar popularized and gained rapid, wide adaptation.

between site type and species size $(\mathrm{p}=0.024)$. Tree growth varied based on site type. Mean separation by Bonferroni on preplanned comparisons of site-type showed there was a difference in growth based upon apparent available soil. Tree size was different by definition (Table 4). The general linear model exhibited an interaction of site type and tree DBH. The small, medium, and large trees have statistically larger DBH in the planting strips and non-limited soil than in the tree pit (Table 2).

\section{DISCUSSION}

Trees in the urban forest face many environmental stresses that are exaggerated in the developed municipal landscape when compared to their natural system counterparts. In order to discuss stand management, an understanding of species senescence and mortality is needed to define a service life end point. From a budgeting perspective, it is hard to manage an urban forest if you are not aware of the end point of the varied species in the 
Table 2. Trees in central and northern New Jersey at the 95th percentile (maximum observed), DBH values including average $\mathrm{DBH}(\mathrm{cm})$ and maximum DBH $(\mathrm{cm})$ observed. Letters within row were deemed statistically significant at alpha $=0.05$.

\begin{tabular}{|c|c|c|c|c|c|c|}
\hline Species & $\begin{array}{l}\text { Pit } \\
\text { Max }\end{array}$ & Average & $\begin{array}{l}\text { Planting strip } \\
\text { Max }\end{array}$ & Average & $\begin{array}{l}\text { Non-limited } \\
\text { Max }\end{array}$ & Average \\
\hline Acer platanoides & 42 & $27.34 \mathrm{a}$ & 27.5 & $27.3 \mathrm{a}$ & 43.5 & $30.7 b$ \\
\hline Acer rubrum & 27.5 & $11.9 \mathrm{a}$ & 41 & $31 b$ & 46 & $32.3 b$ \\
\hline Acer saccharum & $36^{z}$ & $32.1 \mathrm{ab}$ & 34 & $29.4 \mathrm{a}$ & 45 & $34.9 \mathrm{~b}$ \\
\hline Gleditsia triacanthos & 15.5 & $15.5 \mathrm{a}$ & 27.5 & $19.9 \mathrm{a}$ & 45 & $32.1 b$ \\
\hline Platanus $\times$ acerifolia & 42 & $39.3 \mathrm{a}$ & 49 & $38.4 \mathrm{a}$ & 61 & $41.6 \mathrm{a}$ \\
\hline Pyrus calleryana & 21.5 & $18.1 \mathrm{ab}$ & 24 & $17.4 \mathrm{a}$ & 25 & $21.5 b$ \\
\hline Quercus rubra & 34 & $33.5 \mathrm{a}$ & 50 & $38.4 \mathrm{~b}$ & 71 & $48.2 \mathrm{c}$ \\
\hline Tilia cordata & 27.5 & $24.5 \mathrm{a}$ & 39.5 & $31.4 \mathrm{~b}$ & 45 & $36.9 \mathrm{c}$ \\
\hline Zelkova serrata & 9.5 & $9.5 \mathrm{a}$ & 22 & $16.9 \mathrm{~b}$ & 37.3 & $28.7 \mathrm{c}$ \\
\hline
\end{tabular}

${ }^{\mathrm{z}}$ All trees in category were observed to be recommended for removal on condition appraisal.

Table 3. Central and northern New Jersey maximum size expectations. General Linear Model, DBH $(\mathrm{cm})$ versus planting site type and planting tree size and comparisons of means.

\begin{tabular}{llll}
\hline Factor & Type & Levels & Values \\
\hline $\begin{array}{l}\text { Site typology } \\
\text { Species size }\end{array}$ & $\begin{array}{l}\text { fixed } \\
\text { fixed }\end{array}$ & 3 & $\begin{array}{l}\text { non-limited, planting strip, tree pit } \\
\text { large, medium, small }\end{array}$ \\
Source & DF & F & $P$ \\
\hline Site typology & 2 & 26.63 & $<0.001$ \\
Species size & 2 & 187.00 & $<0.001$ \\
Interaction & 4 & 2.81 & 0.024 \\
\hline
\end{tabular}

Table 4. Comparison of DBH means $(\mathrm{cm})$ in species size versus site typology with Bonferroni protection in pre-planned contrasts. Letters in column denote statistical significant at alpha $=0.05$.

\begin{tabular}{llll}
\hline Site typology & \multicolumn{2}{l}{ Species size } & \\
\cline { 2 - 4 } & Small & Medium & Large \\
\hline Non-limited & 26.0 (b) & 57.8 (b) & 94.2 (b) \\
Planting strip & 19.5 (a) & 33.7 (a) & 79.5 (a) \\
Tree pit & 13.8 (a) & 37.8 (a) & 71.4 (a) \\
\hline
\end{tabular}

urban forest. In traditional forest management, harvesting or harvest intervals are in part determined by the maximum size a particular species can reach in a forest, or how long it takes to reach a targeted merchantable size based on its maximum potential. Although, there are many factors that could possibly affect a tree's maximum size in the urban forest, this study focused on tree selection on a site-specific level with the criterion of apparent available soil. Although age is relevant to the urban forest, a more practical criterion for evaluation of maturity is the expected maximum size, and this can break into rapidly defined site types in which the tree species grows as a proxy variable. Most inventories already supply the metrics used in this study and offer the ability to apply the approach to other tree species and regions.

Trees in the 95th percentile reflect when the tree can become a liability to the urban forest as seen in the comments by the arborist who consulted on the project and collected the inventories. For example (Table 1), Acer platanoides, Acer saccharum, and Quercus palustris, trees that were included in the 95th percentile (the maximum size trees) in these species were recommended for immediate removal due to poor condition. This suggests that their useful service life had already been exceeded. The data also illustrated pulses of planting activity (data not shown) as clusters of size, in which a large numbers of trees at a specific DBH were observed. This suggests large planting initiatives that planted certain species at the same time at a common purchased size. These trees will all reach a relative maturity at the same time within a site type, potentially causing an entire portion of the urban forest to be removed for risk at the same time. The urban forest needs to be managed for the future to avoid an even-aged population in which all trees would be dying at the same time. In traditional silvicultural forest management, even-age stands can be useful as some species regenerate better this way. As the urban forest is typically manually planted, it may be wiser to move towards stands of uneven-age for a given species to protect against loss of a certain proportion of the canopy cover due to when the species reaches a maximum DBH. Knowing the maximum DBH for a given species would allow urban foresters to estimate how rapidly they are approaching this potential end point for a species and begin selective harvesting and replanting over time with the goal of moving toward a mixed-aged stand. As such, the urban forest should be managed on a schedule in which trees are planted in multiple years to enable a cropping rotation to determine an uneven-aged stand management. For a street renovation planning sequence, there is a possible benefit in planning harvest intervals on a small street-level scale rather than over the entire management zone.

Treated as an aggregated general population in the general linear model, DBH is assumed to be associated with canopy size. Natural form suggests that tree canopy volume is proportional to natural height and DBH. Regardless of the size class of the tree species, reduced planting space resulted in reduced maximum DBH. As trunk size is related to canopy volume, it stands to reason that reduced planting spaces result in reduced canopy volume. For design, problem solving, or planning in the management of the urban canopy and trying to determine the service life of trees, plotting DBH versus tree height or canopy can provide urban forest managers a reasonable estimation of size expectation. Although this study does not definitively identify the cause of reduced growth in urban trees, it does offer a degree of explanation.

Care in the interpretation of results is warranted. While some of the species have been actively planted over the past 30 years (e.g., Pyrus calleryana, Zelkova serrata), their full life expectancy will likely not have been met. Therefore, maximum size criterion will likely need to be adjusted over time until there is a proven stability over multiple inventory updates within a given community, as the 
trees have not yet reached a proven or repeatable maximum size in trunk diameter. As the area of unpaved surface increased in the planting zone, from pavement opening, to linear planting strip to park/lawn situations, the terminal size trunk diameter of the trees increased. While it is understood that performance expectations need to be on a species level, the data can provide guidance on the consequences of varied design choices and expectations on plant performance to scale design intentions with definitive outcomes. This could provide a context for developing urban site index or urban size expectation to help determine harvest interval, the time when trees begin to accrue costs at a greater rate than returning ecosystem services. This study also used 11 cities whereas a manager would typically use this method in one city. Although there are differences in soils, compaction, and other site specific criteria, the relationships described in all 11 communities are consistent and provide for a start of an urban tree size expectation.

Although researchers identified a gradient in the tree size by planting site location, it is not suggested that this is the definitive maximum for these species. Care is needed in the interpretation of these results, but the methods provide a robust and repeatable benchmarking approach for long-term evaluation by managers and researchers. It should also be noted that small trees were observed in small sites; but not in large sites, this is common for the urban forest. Common wisdom dictates that large trees will provide more shade, which is why small trees tend not to be planted in such sites.

\section{CONCLUSION}

In urban forest management, a goal would be to minimize premature tree losses and manage trees to the point at which trees begin to accrue costs at a greater rate than providing ecosystem services. The goal was to establish a method to develop a construct for cohort senescence, which could be easily developed and replicated from existing data in regional inventories. Thus, the method described could be used with existing community tree inventories. This study seeks to improve management by developing consistent site types to use in conjunction with current inventory practices. With this data, maximum size and a reasonable life span has been determined for several tree species and a conceptual framework has been developed. DBH is a viable surrogate for age. Additionally, design plans need to accommodate a reasonable design size expectation to then provide a reasonable idea of services for the associated investment if some service is associated with canopy size/volume. Within such planning and evaluation, this rapid assessment is very useful.

\section{LITERATURE CITED}

Bassuk N., D. Curtis, B.Z. Marranca, B. Neal. 2009. Recommended Urban Trees: Site Assessment and Tree Selection for Stress Tolerance. Urban Horticulture Institute Department of Horticulture Cornell University, Ithaca, New York, U.S. 128 pp.

Berrang, P., D.F. Karnosky, and B.J. Stanton. 1985. Environmental factors affecting tree health in New York City. Journal of Arboriculture 11:185-189.

Bond, J. 2010. Tree condition: Health. Arborist News 19:34-38.

Bond, J. 2012. Urban Tree Health: A Practical and Precise Estimation Method. Urban Forest Analytics LLC, Geneva, New York, U.S. 130 pp.

Cannell, J.J. 1988. Nationally normed elementary achievement testing in America's public school: How all 50 states are above the national average. Educational Measurement Issues and Practice 7:5-9.
Chacalo, A., A. Aldama, and J. Grabinsky. 1994. Street tree inventory in Mexico City. Journal of Arboriculture 20:222-226.

Clark J., N. Matheny, G. Cross, and V. Wake. 1997. A Model of Urban Forest Sustainability. Journal of Arboriculture 23(1):17-30

Day, S.D., and R. Amateis. 2011. Predicting canopy and trunk crosssectional area of silver linden (Tilia tomentosa) in confined planting cutouts. Urban Forestry \& Urban Greening 10:317-322.

Fraenkel, J.R., and N. Wallen. 1992. How to Design and Evaluate Research in Education. McGraw-Hill, New York, U.S. 620 pp.

Gerhold, H., N. Lacasse, and W. Wandell. 1993. Street Tree Factsheets. Penn State College of Agriculture Sciences, University Park, Pennsylvania, U.S.

Grabosky, J., and E. Gilman. 2004. Measurement and prediction of tree growth reduction from tree planting space design in established parking lots. Journal of Arboriculture 30:154-164.

Hightshoe, G. 1988. Native Trees, Shrubs, and Vines for Urban and Rural America. A Planting Design Manual for Environmental Designers. John Wiley and Sons, New York, U.S. 819 pp.

Hitchmough, J.D. 1994. The management of trees in the urban landscape. pp. 267-300. In: J.D. Hitchmough (Ed.). Urban Landscape Management. Inkata Press, Sydney, Australia.

Jim, C.Y. 1994. Evaluation and preservation of champion trees in urban Hong Kong. Arboricultural Journal 18:25-51.

NJ DEP Community Forestry. 2011. New Jersey shade tree and community forestry assistance act. Accessed 1/17/2012. <www.state.nj.us/ dep/parksandforests/forest/community/>

Pescott, R.T.M. 1968. Life expectancy and planned replacement. pp. 53-59. In: A.W. Wilkie (Ed.). Proceedings of the symposium on street trees. Australian Institute of Parks and Recreation, Melbourne, Australia.

Sanders J., and J. Grabosky. 2013 (in press). Factors influencing early mortality and survival of New York City street trees in the Urban Forest. Urban Ecosystems.

Schoonjans, F., D. DeBacquer, P. Schmid. 2011. Estimation of population percentiles. Epidemiology 22:750-751.

Sinclair, W.A., and G.W. Hudler. 1988. Tree declines: four concept causality. Journal of Arboriculture 14:29-35.

Solotaroff, W. 1911. Shade Trees in Towns and Cities. John Wiley \& Sons, New York, New York, U.S. 287 pp.

Jessica Sanders (corresponding author)

Casey Trees

3030 12th St NE

Washington D.C., 20017, U.S.

\section{Jason Grabosky}

Rutgers - Ecology Evolution Nat Resources

14 College Farm Road

New Brunswick, New Jersey 08901, U.S.

Paul Cowie

Paul Cowie \& Associates

11 N. Beverwyck Road

Lake Hiawatha, New Jersey 07034, U.S. 
Zusammenfassung. Ein Hauptthema bei der Gegenüberstellung der Anwendung von Forstverwaltungsprinzipien mit Entscheidungen bei urbanem Baumbedeckungsmanagement ist der Mangel an Daten zu Standortvergleichen, Baumgröße und Baumalter. Die Forscher testeten, ob die terminale Größe (Stammdurchmesser) mit dem Standorttyp für Management- und Gestaltungsentscheidungen verlinkt werden kann. Es wurden Daten aus elf Kommunen in New Jersey, U.S. herangezogen. Die Verteilung der Brusthöhendurchmesser (BHD) etabliert regionalisierte Dienstleistungserwartungen von gemeinhin gepflanzten Baumarten pro Standorttyp und dem erwarteten maximalen BHD. Das Ziel bestand darin, eine Methode zur Identifizierung von Bäumen, die innerhalb des Baumkatasters zu vergreisen drohen, aufzuzeigen. Drei allgemeine urbane Landnutzungsflächen wurden hier herangezogen: Baumscheibe, Pflanzstreifen, und offenener Boden. 31 Gattungen waren in so großer Zahl vertreten, dass sie für Arten-spezifische Analysen verwendet werden konnten. Die Arten wurden in kleine, mittelgroße und große Größen klassifiziert, basierend auf den veröffentlichen Höhenerwartungen. Die Autoren dieser Studie entwickelten Quantile zum Auftreten von BHD und der BHD um 95 wurde als die maximale Größenspanne beschrieben. Es gab einen deutlichen Unterschied bei den maximalen Größen zwischen den verschiedenen Standorten. Unabhängig von der Größenklasse der Bäume zeigten die Daten, dass ein reduzierter Pflanzraum auch zu reduzierter Gesamtgröße führt.

Resumen. Uno de los problemas frente a la aplicación de los principios de gestión forestal en decisiones de manejo del dosel de árboles urbanos es la falta de datos que correlacionen sitio, tamaño del árbol y la edad del mismo. Los investigadores probaron si el tamaño terminal (diámetro del tronco) se puede enlazar con el tipo de sitio para su manejo y las decisiones de diseño. Los datos consideraron once comunidades de Nueva Jersey, U.S. La distribución de diámetro a la altura del pecho (DAP) estableció expectativas de vida de las especies comúnmente plantadas por tipo de sitio y diámetro máximo esperado. El objetivo fue desarrollar un método para identificar los árboles que se aproximan a la senescencia en un inventario. Se utilizaron tres tipos comunes del paisaje urbano del sitio: árbol en contenedor, plantación a raíz desnuda y suelo ilimitado. Treinta y un taxones presentes en las grandes poblaciones fueron suficientes para usar en el análisis de especie-específico. Las especies fueron clasificadas en categorías de tamaño pequeño, mediano y grande sobre la base de las expectativas de crecimiento publicadas. Los autores del estudio desarrollaron porcentajes de ocurrencia de DBH y noventa y cinco fueron descritos como rango máximo de tamaño. Hubo una diferencia significativa en los tamaños máximos entre los tipos de sitios de plantación. Independientemente de la clase de tamaño del árbol, los datos mostraron espacio reducido de siembra resultando en reducidos tamaños máximos. 